\title{
Pelatihan Kepemanduan di Desa Wisata Donokerto
}

\author{
Yudi Setiaji ${ }^{1}$, Hardi wahyono ${ }^{2}$, Santosa $^{3}$, Hari Rachmadi ${ }^{4}$, Mohammad Hardi \\ Wahyono ${ }^{5}$ \\ 1,2,3,4,5, Sekolah Tinggi Pariwisata AMPTA, Yogyakarta, Indonesia, Email: \\ hary@ampta.ac.id
}

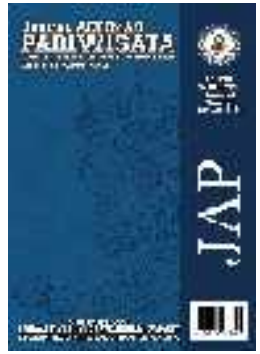

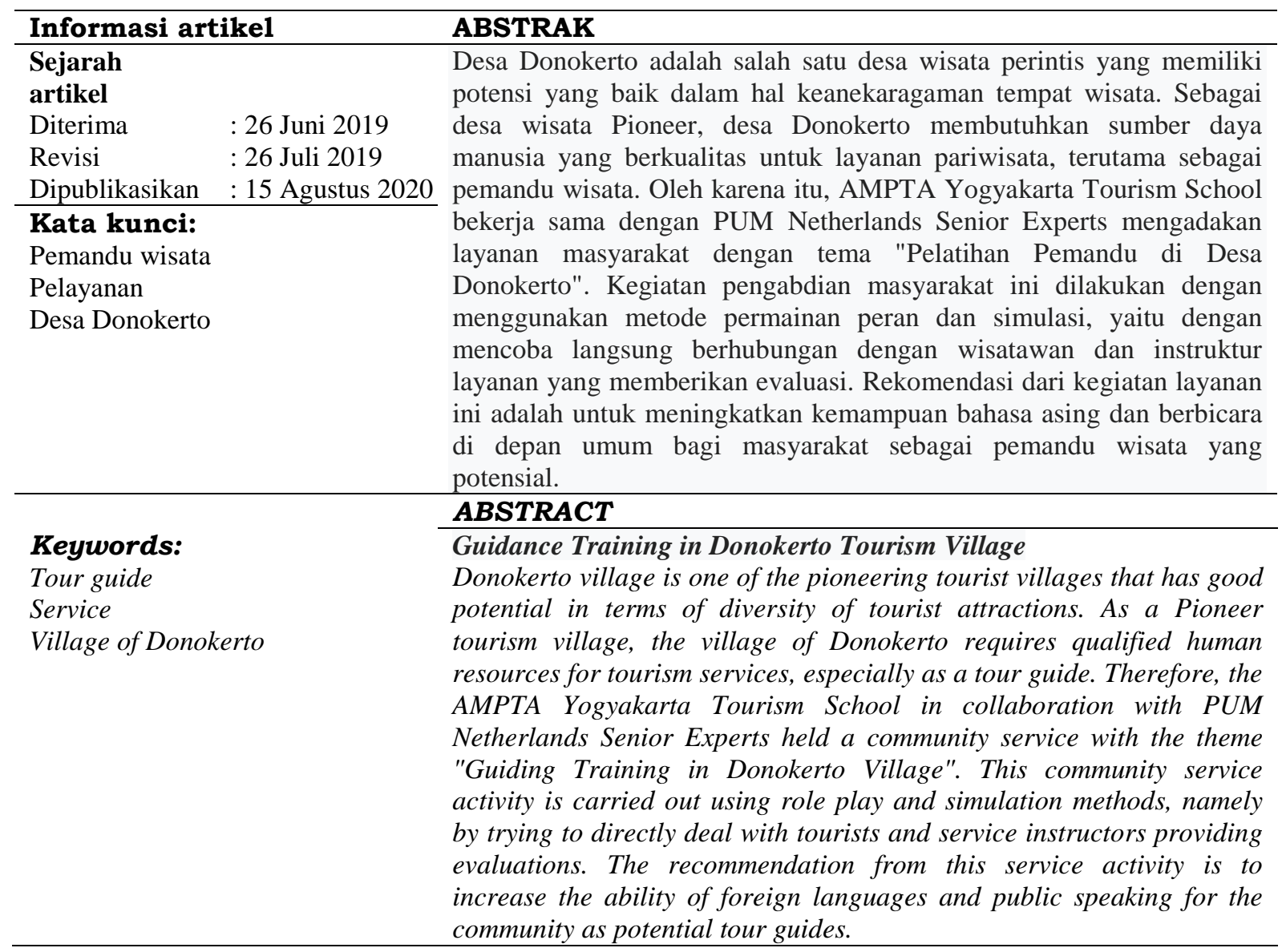

Copyright @2020 Sekolah Tinggi Pariwisata AMPTA. All Right Reserved

\section{Pendahuluan}

Desa Donokerto merupakan salah satu desa yang sedang mengembangkan potensi wisatanya untuk bersiap menjadi Desa Tujuan Wisata. Desa Donokerto memiliki penduduk sebanyak 9.924 jiwa yang memiliki corak hidup masyarakat pedesaan yang masih kental, mayoritas penduduk memiliki pekerjaan utama sebagai petani ("Donokerto, Turi, Sleman," 2019). Faktor alam juga menjadi keunikan tersediri bagi Desa Donokerto, daya dukung lingkunganya yang masih alami dengan sumber air bersih yang melimpah menjadikan daerah ini lokasi yang subur bagi tanaman salak pondoh, buah yang menjadi produk buah unggulan Kabupaten Sleman. Daerah ini juga termasuk lokasi yang ideal untuk perkembangan perikanan dan peternakan lain. Berdasarkan segala potensi yang ada, dapat dikatakan bahwa Desa Donokerto memiliki peluang yang cukup baik untuk berkembang menjadi desa wisata unggulan.

Selaindayatarikwisatasebagaifaktorutamapemicukunjungan, kompetensi sumber daya manusia (masyarkat) sebagai pelaku wisata juga harus dikelola. Mengingat, masyarakat adalah orang-orang ayang akan bersentuhan langsung dengan wisatwan dalam meberikan jasa. Produk wisata selain produk visual berupa pemandangan alam dan lainya, perlu juga didukung dengan produk narasi. 
Produk narasi ini menjadi penting karena akan menambah pengalaman wisatawan selama di destinasi. Produk narasi juga memperngaruhi kepuasan wisatawan. Untuk mewujudkan produk narasi ini diperlukan keterampilan pemandu wisata atau interpreter sebagi penyampai pesan melalui kegiatan pemanduan.

Sebagaidesawisata yang sedang dirintis, Desa Donokerto belum memiliki sumber daya manusia atau masyarakat yang kompeten di bidang pemandu wisata. Padahal peran pemandu wisata sangat penting bagi operasional wisata seperti telah dijelaskan diatas. Oleh karena itu, SekolahTinggiPariwisata AMPTA Yogyakarta bekerjasama dengan PUM Netherlands Senior Experts mengadakan pengabdian masyarakat dengan tema "Pelatihan Kepemanduan Wisata di DesaDonokerto".

Tujuan kegiatan pengabdian ini adalah mengenalkan secara dasar tugas pokok dan fungsi pemandu wisata dalam pelayanan jasa pariwisata, termasuk keterampilan-keterampilan yang diperlukan. Dengan kegiatan pengabdian masyarkat ini diharapkan peserta minimal memiliki pemahaman tentang kepemanduan, dan hal-hal yang perlu disiapkan dan dipelajari untuk menjadi pemandu wisata profesional.

\section{Metode}

Kegiatan pengadian kepada masyarakat ini dilakukan secara bertahap di Desa Donokerto Kecamatan Turi, Kabupaten Sleman, Daerah Istimewa Yogyakarta. Kegiatan pengabdian masyarakan dilakukan pada tanggal 3 Juli 2019. Kegiatan ini dibagi menjadi tiga sesi. Pada sesi pertama kegiatan ini, peserta dikenalkan menganai tugas dan fungsi seorang pemandu dalam kegiatan wisata melalui presentasi. Kemudian pada sesi kedua peserta di ajarkan keterampilan dassar kepemanduan dengan cara praktek langsung (role play) memandu wisatawan. Role play dilakukan bergantian, peserta menjadi pemandu dan rekanya menjadi wisatawan kemudian selanjutnya bertukan posisi. Melalui role play seperti ini diharapkan peserta merasakan secara langsung sensasi dan tekanan saat menjadi pemandu, dan mampu belajar melalui pengalaman. Sesi terakhir adalah evaluasi, yaitu semua peserta akan dikumpulkan dan diberi pengarahan terkait kelebihan dan kekurangan masing-masing, serta hal-hal apa yang harus diperbaiki untuk meningkatkan keterampilanya sebagai seoarang pemandu wisata.

\section{Hasil dan Pembahasan}

Kegiatan pengadian masyarakat berlangsung dengan lancar pada sesi pertama, serta terjadi diskusi yang interaktif, adapun hal-hal yang dipresentasikan dalam sesi pertama meliputi keterampilan dasar sebagai seorang pemandu wisata berikut:

Ada beberapa point yang perlu diperhatikan memandu wisatawan, diantaranya:

1. Memiliki informasi faktual yang memadai tentang karakteristik destinasi yang disampaikan. Olehkarena itu seorang pemandu wisata harus banyak membaca literasi berupahasil penelitian ataupun dari sumber tertulis, maupun dari sumber yang tidak dibukukan, seperti kepercayaan yang tumbuh dalam masyarakat, persepsi masyarakat tentang sesuatu, sertain formasi teknis tentang objek.

2. Kemampuan untuk mengungkap kebenaran melalui informasi yang dimiliki.

3. Pemanfaatan informasi untuk menunjukkan keterkaitan antara objek yang sedang diinterpretasi dengan para wisatawan. Keterkaitan ini berbeda untuk kelompok wisatawan yang berbeda, misalnya antara anak-anak dengan dewasa, atau antara wisatawan Jepang dengan wisatawan Eropa atau domestik. Mengkaitkan sesuatu yang ditafsirkan dengan keseharian kelompok wisatawannya

4. Kemampuanuntukmembujuk agar wisatawan menjaditertarik, melaluiketerampilandan media komunikasiuntukmenarikperhatian. Interpreter harus memiliki pemahaman tentang ketertarikan (interest) wisatawan. 
5. Menyampaikan penafsiran secara utuh, tidak memberikan kesan bahwa kita hanya sekedar tahu tetapi paham betul tentang apa yang sedang ditafsirkan.

Beberapa pedoman bagi seorang interpreter/ pemandu wisata alam diantaranya :

1. Ikutilah perkembangan berita terkini baik berita lokal maupun global, termasuk berita-berita isu lingkungan.

2. Bawalah selalu peralatan interpreteran seperti buku catatan lapangan, buku referensi, P3K dan lain-lain.

3. Berilah motivasi pada wisatawan tentang pentingnya isu-isu lingkungan, baik secara lokal maupun global, dengan demikian kunjungan ketempat wisata alam (eco-site) menjadi batu loncatan terhadap upaya konservasi dan berpikir rasional dalam memanfaatkan sumber daya alam, baik di dalam maupun di luar.

4. Membantu memantau dampak-dampak terhadap lingkungan, termasuk kegiatan-kegiatan yang berhubungan dengan wisata.

5. Meningkatkan teknik interpreter dan pengetahuan umum. Sebagai contoh, setiap bulan memberikan laporan resmi pada organisasinya masing-masing berkaitan dengan perkembangan subyek di lapangan.

6. Jangan ragu-ragu untuk menengahi atau memberitahu dengan sopan dan baik apabila terlihat wisatawan melakukan interaksi dengan alam/objek yang bersifat merusak/ mengganggu untuk mencegah dampak yang lebih besar.

7. Belajarlah untuk berkata "saya tidak tahu". Hal yang lebih penting adalah bukan hanya seberapa banyak yang diketahui, tetapi seberapa baiknya interpreter menyampaikan informasi pada wisatawan.

8. Jangan terlalu muluk berjanji pada wisatawan. Sebagai contoh, hari ini kita bisa melihat lumbalumba, atau kita akan melihat penyu, atau satwa lain di habitatnya, karena fenomena alam itu tidak passti.

9. Pakailah perasaan dan berbuatlah jujur.

10. Interpreter adalah pemimpindan model panutan. Sebagai contoh, jika interpreter tidakmembuang sampah sembarangan, mungkin wisatawan pun akan menirunya dan mencoba menghargai alam.

11. Berilah pujian atau penghargaan dengan tulus daripada hanya berkata basa-basi.

Hal-hal yang dapat diinterpretasikan pemandu wisata alam saat sedang menjalankan:

1. Menjelaskan suasana , bentang alam dan lokasi, beserta proses terbentuknya bentang alam, unsurunsur pembentuknya atau manfaatnya bagi kehidupan dan lain sebagainya.

2. Ekosistem alam, hewan tumbuhan dan sebagainya (fungsi, peran, ancaman terhadap habitat dan populasinya).

3. Menumbuhkan rasa empati wisatawan, misalnya jika manusia berada dalam kondisi atau situasi ancaman dan kehancura nseperti pada adanya bencana di taman yang sedang dikunjungi.

4. Mengajukan pertanyaan yang bersifat memancing wisatawan

Tingkatan penyampaian pesan kepada wisatawan juga perlu menjadi perhatian seorang intepreter, tingkat penyampaian pesan meliputi :

1. Tingkat pendekatan, lakukan aktivitas untuk menarik perhatian wisatawan, salah satunya dengan perkenalan, diskusi, atau permainan.

2. Tingkat pengalaman, ajaklah wisatawan untuk merasakan kelima indera perasa. Contohnya adalah mempersilahkan wisatawan untuk mengamati dan menikmati keindahan Gunung Berapi.

3. Tingkat menemukan dan tertarik, pengujung sadar akan sesuatu. Salah satu caranya adalah bertanya pada mereka.

4. Tingkat Interpretasi, seorang interpreter harus menjawab pertanyaan dengan ilmu pengetahuan dan informasi yang ada. Interpreter memberikan pengalaman yang berkesan kepada wisatawan, sehingga pengalaman itu tertanam dalam pikiran wisatawan.

5. Tingkat Pengembangan, bilasetelah program wisatawan merubah pola hidupnya, maka itu berarti seorang pemandu wisata telah melakukan interpretasi dengan hebat (Dirgantara, 2012; dan Hermawan \& Brahmanto, 2018).

Pada sesi berikutnya adalah sesi praktek, pada sesi ini peserta diminta untuk memprektikan cara melakukan pemanduan wisata. Pada sesi ini peserta sangat antusias mempraktikan teori yang dielajari dengan sangat percaya diri. Peserta memiliki modal dasar yang sangat baik sebagai pemandu yaitu keramah-tamahan (hospitality), meskipun dari segi kemampuan teknis masih sedikit kurang. Peserta 
terkadang masih mengalami kebingungan tentang hal apa yang harus diceritakan kepada wisatawan, walaupun sebenarnya materi yang dapat disampaikan cukup banyak. Misalnya menyampaikan tentang tanaman perdu yang ada di Desa, "Apa nama tanaman tersebut? Kenapa tanaman tersebut di tanam di pekarangan rumah warga? Untuk apa manfaat tanaman tersebut?" Hal ini masih wajar terjadi karena memang peserta baru pertama kali melakukan pemanduan wisata. Solusi yang dapat dilakukan dalam menyampaikan narasi dapat berpedoman pada 5W 1H (what: apa?, Who: siapa, Why: kenapa, When: kapan, Where: dimana)ditambah (How: bagaimana dapat terjadi?) Kedala berikutnya adalah kemampuan bahasa Inggris peserta yang masih kurang.

Sesi ketiga adlah sesi evaluasi, pada sesi ini narasumber menyampaikan kelebihan dan kekurangan masing-masing peserta. Termasuk hal-hal apa yang perlu dipelajari untuk meningkatkan kemampuan dalam segi teknis dan mental peserta.

\section{Simpulan}

Kegiatan pengabdian Pelatihan Kepemanduan di Desa Donokerto berjalan dengan lancar. Antusiasme peserta untuk belajar juga sangat tinggi. Kemampuan peserta cukup baik dalam menerima materi, peserta juga memiliki dasar keramahtamahan yang baik, hanya saja butuh peningkatan kepercayaan diri melalui latihan secara terus menerus, khususnya dalam hal berbicara di depan umum (public speaking). Selain itu, perlu juga dilakukan peningkatan kemampuan dalam segi bahasa asing.

\section{Referensi}

Dirgantara, A. R. (2012). Peran Interpreter dalam Kegiatan Geowisata: Studi Kasus Gunung Tangkuban Perahu. Retrieved from www.academia.edu

Donokerto, Turi, Sleman. (2019). Retrieved June 16, 2019, from https://id.mwikipedia.org Hermawan, H., \& Brahmanto, E. (2018). Geowisata Perencanaan Pariwisata Berbasis Konservasi. Pekalongan: Penerbit NEM. 